\title{
Effectiveness of Using 2D Animation Video with Live Shoot Motion Graphic
}

\author{
Fandy Neta $^{1}$, Rina Yulius ${ }^{2}$, Muchamad Fajri Amirul Nasrullah ${ }^{3}$ \\ ${ }^{1}$ Informatics Department, Politeknik Negeri Batam, Indonesia \\ ${ }^{2}$ Informatics Department, Politeknik Negeri Batam, Indonesia \\ ${ }^{3}$ Informatics Department, Politeknik Negeri Batam, Indonesia \\ Corresponding Author's Email: fandyneta@polibatam.ac.id
}

\begin{abstract}
Programming is not just about writing programs that are "as long as they are", "as long as they can run", "as long as they can deliver the results they expect". Programming requires good methods, techniques, and methodologies so that the written program is an effective program. It is true that many people can make programs, but only a few can program properly. In current technological developments, Algorithms play an imperative part in the field of programming. Especially in the lectures of the Department of Informatics, its relationship is strong with its specific algorithmic programming for students of Multimedia Engineering and Network Study Program. An understanding of algorithms is needed so that it can make the program more effective and efficient. To be able to help students understand the Algorithm and programming material, suitable learning media are important. Media that can be used are 2D Animation Video and Live Shoot Motion Graphic. Given the development of learning media in the form of 2D Animation Video and Live Shoot Motion Graphic that can help students understand the concepts of Algorithms and Programming, it is necessary to conduct research related to testing the effectiveness of learning. This study compares the effectiveness of the use of 2D Animation Video with Live Shoot Motion Graphic on the first-semester student of Multimedia Engineering and Network, Politeknik Negeri Batam. The results of this study indicate that learning using $2 \mathrm{D}$ video with live shoot motion graphics is relatively better than learning using power-point.
\end{abstract}

Keywords: algorithm, live shoot, motion graphics

\section{INTRODUCTION}

(Fuad \& Harisun, 2019) stated that in the world of education in Indonesia, the development of ICT began to have a positive impact due to its significant changes. However, the availability of communication infrastructure that is still minimal causes everyone to obtain information and knowledge to be limited. This is due to the uneven distribution of information and communication technology, only in big cities that have easily enjoyed and utilized the available facilities. One of the impacts is that the development of education is hampered and uneven. Another obstacle experienced by Indonesia in terms of education is curriculum 
constraints that often change so that it will also affect the learning system in schools. Educators are often confused in responding to this and the impact will go directly to students. This has become a serious problem affecting the world of education in Indonesia today which makes the quality of Indonesian education low compared to other countries.

Many factors are indicated as ineffective causes of student learning outcomes, including the method of learning that is applied is still conventional, teachers do not associate the learning material with problems in the surrounding environment, learning models still make lecturers as the main source of knowledge/information and do not use adequate learning media. In terms of media, it takes educators 'creativity to design application products that can effectively and efficiently improve students' abilities in achieving critical thinking and improve other learning competencies. The development of interactive multimedia-based learning media is expected to be effective and efficient in improving the quality of teaching and learning, both for teachers and for their students.

The use of instructional media is closely related to improving the quality of learning expected. The use of instructional media by teachers is expected to create a more meaningful learning experience, facilitate the process of interaction between students and releasing teachers everywhere, and enrich students' learning experiences. This is believed to be able to change the atmosphere of passive learning to be active and more interactive. Learners actively discuss and search through the various learning resources available, while the teacher has the role of being a facilitator who is equally involved in the learning process. The availability of a diversity of media and learning technologies can help students flexibly to achieve their learning goals. The development of interactive media is very important to overcome the shortcomings and limitations of existing media supplies. Media that is developed by the teacher can optimize the mastery of the material by the teaching participants. More than that, it can also increase the creativity and innovation ability of teachers so that the instructor's professionalism is produced (Baharuddin, 2011).

Students of Multimedia and Network Engineering Study Program Department of Informatics Engineering at Politeknik Negeri Batam who take courses in Algorithm and Programming are also inseparable from various obstacles and problems encountered in learning, including the lack of students' ability to understand learning concepts due to their inability to identify and understand problems, the low level of critical thinking of students and the lack of development of social behavior, motivation and cooperation among students and in general students are still being rigid, closed and seemingly distant to their lecturers. 
Therefore, it is fundamental to develop learning media which can stimulate student learning motivation and increase interaction between students and lecturers. Politeknik Negeri Batam as a vocational tertiary institution continues to develop and innovate the learning system to meet the needs of learning. One of them is developing learning assisted learning videos. Multimedia and network study programs become facilitators to develop this learning media. The products produced include 2D learning videos and live videos with motion graphics.

\section{LITERATURE REVIEW}

According to (Rosch, 1996) multimedia can be interpreted as a combination of computer and video. A combination of at least two input or output media. This media can be in the form of audio (sound, music), animation, video, text, graphics and images. Furthermore, (Hofstetter, 2001) defines multimedia as the use of computers to create and combine text, graphics, audio, moving images (video and animation) by combining links and tools that permit user to explore, interact, design, and convey..

Multimedia-based learning projects are teaching methods where students obtain new capability in the process of designing, planning, and producing multimedia products. Media in learning incorporates a work as a tool has a function as a tool to clarify the message passed on by the instructor. Media also functions for individual learning where the position of the media completely serves the learning needs of students.

(Sriadhi, Gultom, Restu, \& Simarmata, 2018) uncovered the impact of multimedia exploratory tutorial model on the learning outcomes of Basic Competence (BC) and Advanced Competency (AC) based on the students'visual capacity contrasts within the course of Transformator. Meanwhile, (Pratama, Arief, \& Hidayati, 2018) applied animation film media to narrative writing skill so that later it can be known the influence or significance of animation film usage in narrative writing skill. Furthermore, (Oktavianingtyas, Salama, Fatahillah, Monalisa, \& Setiawan, 2018) create an intuitive learning media in the shape of 3D animated story with Lectora Inspire and Plotagon on coordinate and reverse extent subject that can be accessed online on computer or android. This study aims to compare the effectiveness of the use of 2D Animation Video with Live Shoot Motion Graphic on the first-semester student of Multimedia Engineering and Network, Politeknik Negeri Batam.

\section{METHODOLOGY}

This study was a quasi-experimental since there is no randomization before assessment conducted. The design methodology illustrated in Table 1 as follows. 
Table 1. Control Group Postest Design

\begin{tabular}{|c|c|c|c|}
\hline Group & Pretest & Treatment & Postest \\
\hline 1 & $\mathrm{~T} 1$ & $\mathrm{X} 1$ & $\mathrm{~T} 2$ \\
\hline 2 & $\mathrm{~T} 1$ & $\mathrm{X} 2$ & $\mathrm{~T} 2$ \\
\hline 3 & $\mathrm{~T} 1$ & $\mathrm{X} 3$ & $\mathrm{~T} 2$ \\
\hline
\end{tabular}

Notes:

1 : Experiment Group (using 2D animation)

2 : Experiment Group

3 : Control Group

$\mathrm{X} 1$ : learning using 2D animation video

$\mathrm{X} 2$ : learning using live video plus motion graphic

$\mathrm{X} 3$ : learning using powerpoint slide

T1 : pretest

$\mathrm{T} 2$ : posttest

To investigate whether there is interaction between learning media and student learning outcomes, this study proposes the following hypotheses:

HO : there is no significant difference between students' understanding of the programming of algorithm introduction material by the use of instructional video media

H1 : there is a significant difference in students' understanding of the programming subjects for introducing algorithms by the use of instructional video media

\section{RESULTS AND DISCUSSION}

Before conducting hypothesis testing using the $t$ test, there are conditions that must be met, namely normally distributed data and variations between homogeneous groups as follows:

1. Normality Test

\section{a. Pretest-Postest on Group 1}

Table 2. Normality Test on Post-test Group 1 (one-sample Kolgomorov-Smirnov)

\begin{tabular}{|ll|r|r|}
\hline & & Pretest_K1 & Postest_K1 \\
\hline Normal Parameters & a & 31 & 31 \\
& Mean & 55.65 & 80.97 \\
& Std. Deviation & 8.731 & 8.110 \\
Most Extreme Differences & Absolute & .160 & .162 \\
& Positive & .160 & .116 \\
& Negative & -.143 & -.162 \\
Kolmogorov-Smirnov Z & & .893 & .903 \\
Asymp. Sig. (2-tailed) & & .402 & .389 \\
\hline
\end{tabular}

a. Test distribution is Normal. 
Table 2 depicted the meaning of group 1 data (learning with 2D video) which is assumed to be normal with asymp. Sig. $>0.050$. Meanwhile, there are differences in the results before and after $2 \mathrm{D}$ video was implemented as illustrated in Table 3 and Table 4 . It can be summarized as $\mathrm{t}$ arithmetic $>\mathrm{t}$ table $(\mathrm{df} 30=2,042)$

Table 3. Paired Samples Statistics

\begin{tabular}{|ll|r|r|r|r|}
\hline & & Mean & N & Std. Deviation & Std. Error Mean \\
\hline Pair 1 & Pretest_K1 & 55.65 & 31 & 8.731 & 1.568 \\
& Postest_K1 & 80.97 & 31 & 8.110 & 1.457 \\
\hline
\end{tabular}

Table 4. T- Test on Post-test Group

\begin{tabular}{|c|c|c|c|c|c|c|c|c|}
\hline & \multicolumn{5}{|c|}{ Paired Differences } & $\mathrm{t}$ & $\mathrm{df}$ & Sig. (2-tailed) \\
\hline & \multirow[b]{2}{*}{ Mean } & \multirow{2}{*}{$\begin{array}{c}\text { Std. } \\
\text { Deviation }\end{array}$} & \multirow{2}{*}{$\begin{array}{l}\text { Std. Error } \\
\text { Mean }\end{array}$} & \multicolumn{2}{|c|}{$\begin{array}{l}95 \% \text { Confidence } \\
\text { Interval of the } \\
\text { Difference }\end{array}$} & & & \\
\hline & & & & Lower & Upper & & & \\
\hline $\begin{array}{ll}\text { Pair } & \text { Pretest_K1 - } \\
1 & \text { Postest_K1 }\end{array}$ & 25.323 & 7.323 & 1.315 & 28.009 & 22.636 & 9.253 & 30 & .000 \\
\hline
\end{tabular}

\section{b. Pretest-Postest on Group 2}

Table 5. Normality Test on Postest Group 2 (One-Sample Kolgomorov-Smirnov)

\begin{tabular}{|ll|r|r|}
\hline & & Pretest_K2 & Postest_K2 \\
\hline $\mathrm{N}$ & & 21 & 21 \\
Normal Parameters $^{\mathrm{a}}$ & Mean & 55.95 & 80.24 \\
& Std. Deviation & 7.684 & 7.999 \\
& & .168 & .113 \\
Most Extreme Differences & Absolute & .168 & .086 \\
& Positive & -.124 & -.113 \\
& Negative & .772 & .520 \\
Kolmogorov-Smirnov Z & & .591 & .950 \\
Asymp. Sig. (2-tailed) & & & \\
\hline
\end{tabular}

a. Test distribution is Normal.

Table 5 depicted the meaning of group 2 date (learning ith live video plus motion graphic) which is assumed to be normal with asymp. Sig. $>0.050$. Furthermore, there are differences in the results before and after live video plus motion graphic was implemented as illustrated in Table 6 and Table 7. It can be summarized as $\mathrm{t}$ arithmetic $>\mathrm{t}$ table ( $\mathrm{df} 20=2,086$ ) 
Table 6. Paired Samples Statistics

\begin{tabular}{|rr|r|r|r|r|}
\hline & Mean & \multicolumn{1}{c|}{$\mathrm{N}$} & Std. Deviation & Std. Error Mean \\
\hline & & & & \\
\hline Pair 1 & Pretest_K2 & 55.95 & 21 & 7.684 & 1.677 \\
& Postest_K2 & 80.24 & 21 & 7.999 & 1.746 \\
\hline
\end{tabular}

Table 7. Normality Test on Postest Group 2

\begin{tabular}{|c|c|c|c|c|c|c|c|c|}
\hline & \multicolumn{5}{|c|}{ Paired Differences } & $\mathrm{t}$ & df & $\begin{array}{l}\text { Sig. (2- } \\
\text { tailed) }\end{array}$ \\
\hline & \multirow[b]{2}{*}{ Mean } & \multirow{2}{*}{$\begin{array}{c}\text { Std. } \\
\text { Deviation }\end{array}$} & \multirow{2}{*}{$\begin{array}{c}\text { Std. Error } \\
\text { Mean }\end{array}$} & \multicolumn{2}{|c|}{$\begin{array}{l}95 \% \text { Confidence } \\
\text { Interval of the } \\
\text { Difference }\end{array}$} & & & \\
\hline & & & & Lower & Upper & & & \\
\hline $\begin{aligned} \text { Pair } 1 & \text { Pretest_K2 - } \\
& \text { Postest_K2 }\end{aligned}$ & 24.286 & 7.417 & 1.619 & 27.662 & 20.909 & 15.005 & 20 & .000 \\
\hline
\end{tabular}

\section{c. Pretest-Postest on Group 3}

Table 8. Normality Test on Postest Group 3 (One-Sample Kolmogorov-Smirnov Test)

\begin{tabular}{|ll|r|r|}
\hline & & Pretest_K3 & Postest_K3 \\
\hline $\mathrm{N}$ & & 21 & 21 \\
Normal Parameters $^{\mathrm{a}}$ & Mean & 49.52 & 72.62 \\
& Std. Deviation & 7.731 & 9.108 \\
Most Extreme Differences & Absolute & .245 & .190 \\
& Positive & .245 & .190 \\
& Negative & -.184 & -.145 \\
& & 1.121 & .869 \\
Kolmogorov-Smirnov Z & & .162 & .437 \\
Asymp. Sig. (2-tailed) & & & \\
\hline
\end{tabular}

a. Test distribution is Normal.

Table 8 depicted the meaning of group 3 data (learning with powerpoint slide) which is assumed to be normal with asymp. Sig. $>0.050$. Furthermore, there are differences in the results before and after live video plus motion graphic was implemented as illustrated in Table 9 and Table 10. It can be summarized as $t$ arithmetic $>t$ table (df $20=2,086$ )

Table 9. Paired Samples Statistics

\begin{tabular}{|c|c|c|c|c|c|}
\hline & & Mean & $\mathrm{N}$ & Std. Deviation & Std. Error Mean \\
\hline \multirow[t]{2}{*}{ Pair 1} & Pretest_K3 & 49.52 & 21 & 7.731 & 1.687 \\
\hline & Postest_K3 & 72.62 & 21 & 9.108 & 1.987 \\
\hline
\end{tabular}


Table 10. Normality Test on Postest Group 3

\begin{tabular}{|c|c|c|c|c|c|c|c|c|}
\hline & \multicolumn{5}{|c|}{ Paired Differences } & $\mathrm{t}$ & df & $\begin{array}{l}\text { Sig. (2- } \\
\text { tailed) }\end{array}$ \\
\hline & \multirow[b]{2}{*}{ Mean } & \multirow{2}{*}{$\begin{array}{c}\text { Std. } \\
\text { Deviation }\end{array}$} & \multirow{2}{*}{$\begin{array}{l}\text { Std. Error } \\
\text { Mean }\end{array}$} & \multicolumn{2}{|c|}{$\begin{array}{l}95 \% \text { Confidence } \\
\text { Interval of the } \\
\text { Difference }\end{array}$} & & & \\
\hline & & & & Lower & Upper & & & \\
\hline $\begin{aligned} \text { Pair } 1 & \text { Pretest_K3 - } \\
& \text { Postest_K3 }\end{aligned}$ & -23.095 & 7.687 & 1.677 & -26.594 & -19.596 & -13.768 & 20 & .000 \\
\hline
\end{tabular}

\section{Homogeneity Test}

Homogeneity test is utilized to ascertain whether several population variants are the same or not. This test is performed as a prerequisite within the investigation of independent sample $t$ test and ANOVA. The underlying assumption in variance analysis (ANOVA) is that the variance of the population is the same. As a testing criterion, if the significance value is more than 0.05 , it can be said that the variants of two or more groups of data are the same. ANOVA score was presented in Table 11, while the result of homogeneity test (using Duncan score) on pretest data was illustrated in Table 12.

Table 11. Score of ANOVA

\begin{tabular}{|l|r|r|r|r|r|}
\cline { 2 - 6 } \multicolumn{1}{c|}{ Score } & & & & & \\
\hline & Sum of Squares & df & Mean Square & F & \multicolumn{1}{c|}{ Sig. } \\
\hline Between Groups & 16.360 & 2 & 8.180 & .110 & .896 \\
Within Groups & 5191.859 & 70 & 74.169 & & \\
Total & 5208.219 & 72 & & & \\
\hline
\end{tabular}

Table 12. Duncan Score

\begin{tabular}{|c|c|c|}
\hline \multirow{2}{*}{ GROUP } & & Subset for alpha $=0.05$ \\
\cline { 3 - 3 } & $\mathrm{N}$ & 1 \\
\hline 3 & 21 & 54.76 \\
1 & 31 & 55.65 \\
2 & 21 & 55.95 \\
Sig. & & .659 \\
\hline
\end{tabular}

Means for groups in homogeneous subsets are displayed.

Based on the data processing homogeneity test known value of Sig. 0.896> 0.05 so that it can be concluded that the post-test variance of the experimental class and the post-test control class are the same or homogeneous. 


\section{Hypotheses Testing}

To indicate whether the experimental group and the control group after each carry out learning by using a different approach really have different abilities to understand the concept, it is necessary to test the hypothesis against the calculation of ANOVA posttest scores as shown in the Table 13 until HO is rejected. Overall, it can be concluded that after the study was conducted, the average ability of students in the experimental group and the control group was not the same. Based on Tables 14, the average posttest score of the experimental group with 2D video is equal to 80.97 and the live shoot with motion graphic video group is 80.24 , while the control group has an average of 72.62 .

Table 13. ANOVA Score

\begin{tabular}{|l|r|r|r|r|r|}
\cline { 2 - 6 } \multicolumn{1}{l|}{ SCORE } & & & & & \\
\hline & Sum of Squares & df & Mean Square & F & \multicolumn{1}{c|}{ Sig. } \\
\hline Between Groups & 1834.517 & 2 & 917.258 & 15.384 & .000 \\
Within Groups & 4173.730 & 70 & 59.625 & & \\
Total & 6008.247 & 72 & & & \\
\hline
\end{tabular}

Table 14. Duncan Score

\begin{tabular}{|l|r|r|r|}
\hline \multirow{2}{*}{ GROUP } & & \multicolumn{2}{|c|}{ Subset for alpha $=0.05$} \\
\cline { 3 - 4 } & $\mathrm{N}$ & 1 & \multicolumn{1}{c|}{2} \\
\hline 3 & 21 & 69.62 & \\
2 & 21 & & 80.24 \\
1 & & & \\
Sig. & & & \\
\hline
\end{tabular}

Means for groups in homogeneous subsets are displayed.

Based on Table 13, F value was obtained as 15,384 with a Sig value of 0,000. Because Sig is smaller than $0.05, \mathrm{H} 0$ is rejected. This is a significant difference between significant learning outcomes. The significance of students on courses and programming algorithms. K3 (control) has 69.62 different learning outcomes from K2 (2D Video) and K3 (Live Shoot Motion Graphic). But the K2 and K3 groups do not have different abilities.

\section{CONCLUSION}

There is a significant difference regarding the students' understanding of the subject of algorithm introduction material programming by the use of instructional video media. Overall, learning using live shoot video plus motion graphic give the most significant effects on learning algorithm subject. 


\section{ACKNOWLEDGMENT}

This study was sponsored by the Center for Research and Community Service of Politeknik Negeri Batam. We thank our colleagues from the Department of Informatics Engineering of Politeknik Negeri Batam who provided insight and proficiency that significantly assisted the study.

\section{BIODATA}

Fandy Neta is a lecturer in video editing, photography, and graphic design in Informatics Engineering Dept, Politeknik Negeri Batam, Indonesia.

Rina Yulius is a lecturer of the Informatics Engineering Dept on Politeknik Negeri Batam, Batam, Indonesia. She has a research interest in gamification, humancomputer interaction, and UX/UI.

Muchamad Fajri Amirul Nasrullah is a lecturer of mobile programming and videography in the Informatics Engineering Dept, Politeknik Negeri Batam, Indonesia.

\section{REFERENCES}

Baharuddin. (2011). Teori Belajar dan Pembelajaran. Yogyakarta: Ar-ruzzmedia. Fuad, A., \& Harisun, E. (2019). Analisis Tingkat Kepuasan Mahasiswa Terhadap Kinerja Sistem Informasi Akademik (SIMAK) Di Program Studi Informasi. Jurnal Informatika Dan Komputer, 03(1).

Hofstetter, F. (2001). Multimedia Literacy. New York: McGraw-Hill.

Oktavianingtyas, E., Salama, F. S., Fatahillah, A., Monalisa, L. A., \& Setiawan, T. B. (2018). Development 3D Animated Story as Interactive Learning Media with Lectora Inspire and Plotagon on Direct and Inverse Proportion Subject. Journal of Physics: Conference Series, 1108(1). https://doi.org/10.1088/1742-6596/1108/1/012111

Pratama, A., Arief, D., \& Hidayati, A. (2018). The Effect of Using Animated Media Films and Entering Behavior to Narrative Writing Skill in Indonesian Language Learning Class V, 263(Iclle), 223-228. https://doi.org/10.2991/iclle-18.2018.37

Rosch. (1996). Easy Way to Understand the Multimedia. Bostom: Allyn and Bacom.

Sriadhi, S., Gultom, S., Restu, R., \& Simarmata, J. (2018). The Effect of Tutorial Multimedia on the Transformator Learning Outcomes Based on the Students' Visual Ability. IOP Conference Series: Materials Science and Engineering, 384(1). https://doi.org/10.1088/1757-899X/384/1/012059 